\title{
The power of a powerless woman: examining the impact of violence on a Biblical nation
}

Elizabeth Tracy*

\begin{abstract}
She is nameless and without voice, viciously raped and murdered. The story of the Levite Concubine or Pilegesh, as told in the last three chapters of the Book of Judges, is often referred to by scholars as an appendix, unworthy to be considered part of the pantheon of illustrious judges in Israel. However, the account of the gang rape and murder of a defenseless and socially insignificant woman is more than a story of violence against women. It is the story of consequences of violence and the power one woman can have over an entire nation.
\end{abstract} Keywords: Book of Judges. Levite. Concubine. Rape. Murder. Judges 19-21.

The Oxford Dictionary of Jewish Religion begins its definition of homicide with the following;

"Thou shalt not murder" (Exod. 20:13) is one of the Ten Commandments; willful murder is a capital crime for which no expiation is possible other than the forfeiture of the life of the murderer (Num. 35:31-33). Failure to expiate the crime of murder renders society guilty (Deut. 19:10) and the land polluted (Num. loc. cit.) (BERLIN, 2011, p. 358).

Marvin Sweeney (1997) states that scholars have for years read Judges "as a historical source that reflects the historical and social

\footnotetext{
"She holds a PhD in Hebrew Bible from the University of St Andrews, Scotland. E-mail: bethtracy@hotmail.com.
} 
The power of a powerless woman: examining the impact of violence...

realities of pre-monarchic Israel". He goes on to advocate that, "Judges must also be read as a literary work that presents a specific socio- political and religious understanding of Israel" (SWEENEY, 1997, p. 517). The gang rape of a woman and the ensuing results are most often viewed through a strictly social lens but the Deuteronomistic Historian consistently presents history in terms of covenants (FRIEDMAN, 1997, p. 104). If the social and covenant perspectives are combined the Levite's pilegesh can no longer be listed simply as a victim. She must be held up as a powerful symbol of judgment for an entire nation. She becomes, potentially, the most powerful judge in all of Israel.

"And it came to pass in those days, when there was no king in Israel, that there was a certain Levite sojourning on the side of mount Ephraim" (Judg. 19:1). So begins the story. The Levite and his pilegesh, defined as a concubine, a wife, or a slave, have marital problems. She leaves him in the territory of Ephraim and goes back to her father's house in Bethlehem-Judah. Four months pass before the Levite travels to Bethlehem to reconcile with her. He and his father-in-law get along, or maybe the father- in-law is trying to make up for his daughter's indiscretions with hospitality, either way, the Levite and his party are delayed returning home. On the evening of the fifth day the Levite, his pilegesh, and a servant finally set off. The sun is setting and they must find a place to stay for the night. The Levite decides that they will not stay in Jerusalem because it is not Israelite territory but must push on to Gibeah, a city near Jerusalem that belongs to the tribe of Benjamin. No one in Gibeah offers them hospitality except an old man, originally from Ephraim territory, who happens to be living in Gibeah.

During dinner an unruly mob comes to the house and demands "to know" the stranger in a sexual context (SCHNEIDER, 2000, p. 260). The host offers his virgin daughter and the pilegesh instead. The mob won't listen to the host or leave so the Levite "took his concubine, and brought her forth unto them" (Judg. 19:25). The chain of verbs describing the Levite's actions convey a strong impression of escalating violence (KEEFE, 1993, p. 81). The verb "brought forth" here has a connotation of seizure not a gentle exit from the house (SCHNEIDER, 2000, p. 261). The mob then gang 
rapes and tortures the woman throughout the night. Finally, in literary slow motion, the pilegesh maneuvers her tortured body to the door step of the house where she is found unresponsive the next morning by the Levite. He picks her up, puts her on a donkey and continues the journey home where he dismembers her body into twelve pieces and sends one piece to the leaders of each of the twelve tribes.

The leaders of the tribes assemble to take action. The Levite relates the story of the murder, while not disclosing all the details, which ensures he is put in a good light (YEE, 2007, p. 156). The tribe of Benjamin is given the opportunity to repent and surrender the perpetrators. They refuse to help apprehend or even punish those responsible for the crime. The tribe then closes rank and refuses to submit themselves to covenant law. Civil war ensues. The entire tribe of Benjamin, including men, women and children, all their cities, and possessions are destroyed except for 600 men who hide out in the wilderness.

Horrified that war has nearly decimated one of the twelve tribes, the remaining families decide to restore the tribe of Benjamin. Unfortunately, they have already covenanted with each other to not allow their daughters to marry any Benjaminite survivors. Wives must be found elsewhere. Women are then forcibly taken from the town of Jabesh-Gilead in Mannaseh. The town had not responded when called to fight and must now pay for their disobedience with their lives while their virgin daughters are taken against their will. Four hundred daughters are given to the Benjaminite survivors. Another two hundred wives are kidnapped from the daughters of Shiloh as they dance outside the city during a festival. The reconstituted tribe of Benjamin is restored to its lands and the narrative ends, "In those days there was no king in Israel: every man did that which was right in his own eyes" (Judg. 21:25).

Martin Noth, in his research on the Deuternonomistic History, showed that the books of Moses and the six books that followed - including the Book of Judges - were not a loose collection of writings, but a thoughtfully arranged work. They "told a continuous story, a flowing account of the history of the people of Israel in their land" (FRIEDMAN, 1997, 103). Many scholars now believe 
this body of literature was arranged in such a way as to emphasize and present a distinct theological perspective (MATTHEWS, 2004, p. 5). If so, then the story told in the last three chapters of the Book of Judges must have significance beyond the obvious brutality of the piece.

Phyllis Trible's analysis of the Levite pilegesh has become a benchmark in scholarly approaches to this difficult story but it is very singular in its purpose.

Of all the characters in scripture, she is the least. Appearing at the beginning and close of a story that rapes her, she is alone in a world of men. Neither of the other characters nor the narrator recognizes her humanity. She is property, object, tool and literary device. Without name, speech, or power, she has no friends to aid her in life or mourn her in death (TRIBLE, 1984, p. 80-81).

The narrator may not recognize her humanity but the Deuteronomistic Historian sees her value and power as a symbol of justice and judgment on an entire nation.

\section{She is powerful because her death defines murder}

In Judges 20:4 the narrator identifies the Levite's pilegesh as "the woman who was slain." The Hebrew word חצר, "to murder", is used to describe the death of the woman. There are 46 occurrences of forms derived from חצר in the Hebrew Bible. From the Decalogue in Exodus 20 through to Judges the majority of these occurrences are contained within laws governing asylum (BOTTERWECK; RINGGREN; FABRY, 1977, p. 631). Because most of the laws governing asylum are in legal lists "it is impossible to determine its precise meaning. In the Bible, the word חצר appears four times in lists in which the behavior indicated by the use of the verb is prohibited. (It never appears in a list in which the behavior is approved or encouraged.)" (BAILEY, 2005, p. 7). Judges 
20:4 is the first time חצר is used in a narrative and it is the only time it takes a feminine form (BROWN; DRIVER; BRIGGS, 2005, p. 953-954). With all due respect to Phyllis Trible, within Judges there are many examples of death by the hand of another, however, none of these stories use the Hebrew word חצר "to murder", which makes the pilegesh unique and much more than a one-dimensional literary device.

The Book of Judges has numerous incidents of killing with stories that capture the imagination of the reader such as Ehud killing Eglon the Moabite king, Jael who drives a tent stake through the head of Sisera, a Canaanite army commander, and Samson who kills thousands of Philistines with the jawbone of an ass. However, the intentional killing in these stories is accepted and sometimes even encouraged. David Noel Freedman studied the nature of these killings. He clarifies that,

[...] this command [ment, to not kill,] applies almost exclusively to personal relations between Israelites, as the killing of Israel's enemies in war is almost always a commendable action, including, at times, women and children, though this is much rarer. In these cases, to spare even one of the enemy could bring a curse on the entire Israelite community (FREEDMAN, 2000, p. 112).

Therefore, the killings mentioned above and others in the Book of Judges are, within their context, considered to be righteous actions performed for the sake of the community.

The rape and death of the pilegesh stands in stark contrast to these righteous killings. Freedman (2000, p. 112-113), after investigating all the examples of killing in the Book of Judges, concluded that a violation of the commandment prohibiting murder must meet the following criteria:

1. The death could not be the result of a suicide (assisted or self-inflicted), or from capital punishment.

2. The death could not be the result of self-defense, the defense of others or an accident. 
The power of a powerless woman: examining the impact of violence...

3. The action resulting in death is taken with malice or forethought.

4. The victim must not be an enemy to Israel.

Freedman then holds the death of the Levite pilegesh, a woman of no social relevance, unnamed, unspeaking and supposedly powerless, as the only event in the book that fits the criteria perfectly. She is, therefore, powerful from the stand point that her death defines murder for the first time in the Hebrew canon.

\section{She is powerful because her death holds individuals accountable}

In Judges 19:28 the Levite picks up the unresponsive pilegesh and puts her on a donkey. When he arrives home he takes the knife, תלכאםה, "and laid hold on his concubine, and divided her, with her bones, into twelve pieces, and sent her into all the coasts of Israel" (Judg. 19:29). The fact that the definite article is used in conjunction with the description of the knife is significant. "The expression, the knife, תלכאםה, appears in the Bible only in the dismemberment of the concubine and in Genesis 22 in relation to Abraham and Isaac" (REIS, 2006, p. 143). The narrator is using subtlety to move the audience in the direction of seeing the tortured pilegesh in terms of a sacrifice but not as a sacred one. By juxtaposing actions of the Levite and Abraham the narrator is setting up a distinction between the two stories. The Levite, a supposed keeper of priestly things, uses the knife to perform an abomination of a sacrifice in complete contrast to the divinely observed sacrifice Abraham was asked to make.

In addition to this allusion, the verb חתנ "to cut in pieces" is only found outside of sacrificial contexts here and in 1 Sam. 11:7 when Saul cuts up an ox (BROWN; DRIVER; BRIGGS, 2005, p. 677). In that passage the action described is taken by Saul to summon the Israelites to war against the Ammorites. 
In the incident in 1 Samuel the act is explained; the same fate of being cut up will befall the cattle of all who fail to obey the summons to battle. [In Judges 19] the action is clearly intended to arouse the horror and indignation of all against those who had perpetrated such an outrage (MARTIN, 1975, p. 206).

Who exactly has committed an outrage, however, is not explicitly defined. In her article "Rapes of Women/Wars of Men" Alice Keefe states that

\begin{abstract}
[...] [t]here is scholarly discussion as to whether the greater outrage was the mob's rape of the woman or their breach of hospitality in regard to the men [which] makes one suspect rampant androcentrism. Beyond these choices, the ambiguity in this response, "such a thing has never happened or been see”, might well refer to the outrageous horror of a piece of a woman's body arriving in town. Indeed, reading out of a perspective where the body of woman is sacred, the Levite's act of calculated dismemberment may be the most disturbing outrage of all (KEEFE, 1993, p. 86).
\end{abstract}

It should be noted that at no time in the Masoretic Text does the narrator give an exact time or cause of the pilegesh's death (SCHNEIDER, 2000, p. 264) ${ }^{1}$. With all the other stories of killing and death in Judges, her demise is the only one without a clear cause of death or assigned responsibility. This ambiguity of time of death and the fact that both the husband and the host have offered the pilegesh to the mob adds to the complicity of all parties involved (KLEIN, 1988, p. 171) beyond just the men of Benjamin. "In biblical law, willfulness or premeditation is established by showing either that a deadly instrument was used (Num. 35:16-18) or that the assailant harbored hatred or enmity toward the victim (Num. 35:20-21; Deut. 19:11)." (COHN; ELON, 2007, p. 506) Without a marked time of death and cause the audience is left with two possibilities and, according to biblical law, two very viable suspects: the Benjaminite attackers or the Levite with "the knife". 


\title{
She is powerful because her death holds an entire nation accountable
}

The text uses the word pilegesh to define the woman's status. The term is most often translated into English as concubine but this is murky and problematic. Tammi Schneider explains,

\begin{abstract}
The English term [concubine] was defined as, "a woman who cohabits with a man without being his wife". The term can also mean secondary wife in certain societies but there is no evidence [in Judges 19-21] of the existence of a primary wife to whom this woman would be second. Neither [English] translation addresses what is implied in terms of marriage, rank, status, legal rights, or inheritance procedures" (SCHNEIDER, 2000, p. 248).
\end{abstract}

Like the ambiguity of her time of death, this vagueness in categorizing the woman only makes her existence more universal and her situation more poignant. Even without a defined position in society, a name, or a voice she still becomes central to the actions of the story.

According to Mosaic tradition, if an individual was not held accountable for his or her crime the entire community became subject to the penalty (FREEDMAN, 2000, p. 118). The story of Achan in Joshua 7 tells the story of a man who confesses to bringing back expressly forbidden spoils of war and, therefore, condemnation on Israel. He pays for his sin with his life and the lives of his entire family. It is a dramatic description of how sin must be cleansed from the community by removing all associated with it.

The responsibility of calling the community together belonged to the appointed judges. However, while there are men and women called to be Judges in Israel, the tribes do not come together en masse until chapters 20-21. Most of the earlier stories feature one or two tribes fighting a common enemy and then dispersing until another event brings a new threat with a new deliverer. Walter Harrelson (1964, p. 129) wrote, 
[...] [t]he tribes were held together by only a few realities: the worship of Yahweh who had brought them out of Egypt and given this new land to them; the sacred history of Yahweh's past dealings with them; the bonds of the confederacy that secured a minimum allegiance to the covenant requirements, participation annually in the covenant ceremony, maintenance of the central sanctuary, and the like; and the necessity of defending any of the tribes when threats arose, together with the necessity of disciplining any tribe for violations of the membership requirements in the confederacy.

What brings the all tribes together in this singular event is their understanding of the covenant, i.e., that the entire tribe of Benjamin has become guilty for the sins of a few of its members. If the single tribe is not punished the collective nation of Israel will carry the same guilt before Yahweh.

Many interpretations say the civil war that follows the death of the pilegesh is due to the outrage of the destruction of the Levite's personal "property", his pilegesh. The more pertinent issue, however, is the fact that the perpetrators of the crime would not confess, the town would not surrender the guilty, and the tribe of Benjamin, "would not harken to the voice of their brethren the children of Israel” (Judg. 20:13). Justification for the war is, in fact, the covenant and belief in the laws of Yahweh. If the woman was only property, and truly of little worth, the Levite would have been compensated with a woman from the tribe of Benjamin and no war would have been fought over her death. Benjamin's tribal crime is gang rape resulting in murder and an unwillingness to admit their sins and repent. Their opposition to cleanse the tribe, a total disregard for the covenants, and a collective contempt for righteousness threaten the entire Israelite nation in their standing before God. 


\section{She is powerful as a symbol of a final opportunity for redemption}

A murder has brought the tribes together. As the combined Israelite army prepares to attack the tribe of Benjamin they seek Yahweh's blessing in the house of God. Since there is no king in Israel and therefore no defined leader they ask, "Which of us shall go up first to battle against the children of Benjamin?” (Judg. 20:18); Yahweh answers that Judah should lead, which is correct according to Genesis 49 where Judah is given a blessing that, "thy father's children shall bow down before thee... The scepter shall not depart from Judah, nor a lawgiver from between his feet, until Shiloh come” (Gen. 49:8,10). Interestingly, after this divine direction, Israel attacks Benjamin and loses 22.000 men. There is no mention of Benjaminite deaths in the narrative.

The Israelite army prepares a second day to attack the tribe of Benjamin. Again, they counsel with Yahweh. This time they ask if they should go up to battle against their brethren (Judg. 20:23). Yahweh tells them to go, which again, is correct according to the covenant they made to protect the sanctity of the nation when they first entered the Promised Land, "whosoever he be that doth rebel against thy commandment, and will not harken unto thy words in all that thou commandest him, he shall be put to death" (Josh 1:18). Israel attacks Benjamin a second time and another 18.000 of their army die.

Humility and repentance finally come into play as the entire nation, except Benjamin, goes up to the House of Yahweh where the Ark of the Covenant is kept. ${ }^{2}$ In the previous days of fighting the tribes relied on worldly questions and concerns. This time they weep and fast, offer burnt offerings and peace offerings in an effort to truly know the will of Yahweh. Phineas, the grandson of Aaron, serves as the high priest before Yahweh and asks, "Shall I yet again go out to battle against the children of Benjamin my brother, or shall I cease?" (Judg. 20:28); Yahweh answers the honest and repentant pleas with, "Go up; for tomorrow I will deliver them into thine hand" (Judg. 20:28). The fighting that follows decimates the entire tribe of Benjamin - men, women, children, cities, and possessions. 
Israel is now on the brink of deliverance from the idolatrous sins of the tribe of Benjamin.

Lillian Klein makes a very interesting statement at this point of the story. She notes that the tribes realize that rape and murder have caused the immanent destruction of an entire tribe but,

Not only do they fail to recognize their own responsibility in the judgment and the ensuing developments, but they end up blaming Yahweh for their getting what they wanted: to punish Benjamin for its protection of those who committed evil in Gibeah (KLEIN, 1988, p. 88).

The remaining tribes take matters into their own hands, forgetting their earlier promises to Yahweh.

In quick succession, without waiting for an answer from Yahweh, they ask, "Why is this come to pass in Israel, that there should be today one tribe lacking in Israel?" (Judg. 21:3). The next day the people rise early and build, somewhere outside the house of God, an altar and offer sacrifices. The questions then asked are, "Who is there among all the tribes of Israel that came not up with the congregation unto the Lord?" (Judg. 21:5) and "How shall we do for wives for them that remain?" (Judg. 21:7). While the first question, regarding the possible loss of the tribe of Benjamin, forgets the covenant made with Yahweh, the following two questions hold covenants made between the tribes as sacrosanct. These questions are balanced by oaths that stated anyone who did not come to Mizpeh to join the fight should be put to death and no daughters were to be given to any survivors of Benjamin as wives (Judg. 21: 5, 7).

In the process of "fixing" the tribe of Benjamin the tribes of Israel commit the same crime of rape and murder, repeating the tragedy of the pilegesh six hundred times over. They murder the residents of Jabesh-Gilead who had not come up to defend the nation and take their virgin daughters to marry the Benjaminite survivors. Two hundred more wives are "found" by kidnapping the daughters of Shiloh who come out to dance. To justify their actions they state, "Be favorable unto [the kidnappers] for our sakes: because we reserve not to each man his wife in the war: for ye did 
not give unto them at this time, that ye should be guilty" (Judg. 21:22). They rationalize their actions using the same justification originally used to justify the civil war in response to the death of the pilegesh. This time, however, they have made the breech themselves with Yahweh. The story ends with "In those days there was no king in Israel" and the narrator adds the caveat, "and every man did that which was right in his own eyes" (Judg. 21:25). One rape and murder of a single socially insignificant woman has now become the rape of six hundred. The sin, like a disease, has spread to the entire tribe.

\section{She is powerful because her story defines iniquity for all future generations}

The story of the Levite pilegesh does not immediately seem to follow the guidelines set up in the previous chapters of the Book of Judges (YEE, 2007, p. 148) where the cycle of apostasy ${ }^{3}$ examines the ever-increasing idolatry within the nation. However, while the last three chapters of Judges have no glorious deliverer, they explicitly follow the pattern. Sin abounds in each of the characters involved in the story, whether explicit or implied. No one is without blemish. The entire nation is in bondage due to the sin of, not only Benjamin, but the multitude of transgressions that are continually being added upon previous sins. There is repentance, but only briefly, and it is not enough to bring about true deliverance.

Richard Elliott Friedman states that the Book of Judges defines prophets as, "men or women who were regarded as having been called by the deity to perform a special task with regard to the people. The task might be to encourage or to criticize. It might be in the realm of politics, ethics, or ritual" (FRIEDMAN, 1997, p. 36). Using this definition, the pilegesh is a potential prophet whose presence criticizes on almost every level and brings a special opportunity for redemption to the entire nation. But, as the last line of the book testifies, the nation had slid even farther into apostasy. Victor Matthews (2004, p. 202) says that this final phrase 
[...] sums up the continual slide of the people into social and political anarchy. Without the leadership, without attention to the covenant or to God's direction, they had the option of 'flying blind' through life. Their lack of any clear code of conduct allowed for rampant violence, intrigue, and haphazard religious practice.

When the prophet Hosea speaks of the current spiritual state of the tribes in his day he references the multitude of crimes described in Judges 19-21 by saying, "They have deeply corrupted themselves, as in the days of Gibeah: therefore God will remember their iniquity, he will visit their sins" (Hos. 9:9). The corruption he refers to is not just the gang rape and murder of a single unnamed woman by men from the tribe of Benjamin. He is holding up a mirror to the people as they face their own imminent destruction due to the sin they have allowed to infect their entire society.

Alice Bach (1999, p. 143) defines rape as "a weapon to reassert the power of a man over an enemy. Rape is used to create fear in women... We have come to understand that rape is not so much a sexual crime as it is a means of physical, mental, and spiritual domination". If the action of rape is defined as power ill-used then a close look at the characters and what they represent during the horrific event are a telling prophetic metaphor.

\section{Conclusion}

James Berkeley (1954, p. 59) observed:

They are books containing history, but in them the history was written as the proclamation of the word of God, that is, as words of prophecy. To the Hebrews, prophets were not only speakers to the present but also were writers of history who told the story of the past to interpret God's will for the present. 
If we look only at the physical death of the pilegesh we follow in the blind footsteps of the Israelites. The power and value of the defenseless should resonate with us today far beyond the disgust of "violence against women". Our individual worth, even if society does not see it, is seen by God and we are still held accountable at all times and in all places for our treatment of the seemingly powerless among us.

The pilegesh was a woman unnamed and without a voice. She was not comforted in life but her existence has definite power. Her death, the result of meaningless violence, is defined as murder. She became a potential judge in Israel in the sense that her death orchestrated the only time all the tribes of Israel worked together to right a wrong. The consequences set in motion by her death show her to be the catalyst for potential redemption. Not only for the people of her time but also for those who come after.

The result of most actions taken by judges in the book is the return of the people to the correct worship of YHWH and the resulting rest in the land. "Ancient historians went about their task in a very different way from modern ones. Historical accuracy was not nearly as important to them as telling a good story and making an important moral point" (BELLIS, 2007, p. 32). The object of Judges 19-21 is not only to highlight inhospitality, sexual perversion or gender bias. It also records the last attempt to force the nation of Israel to return to an acceptable and accurate practice of the worship of YHWH. The narrator, in choosing a unique feminine particle form of the verb חצר to describe the death of a nameless woman, declares the moral bankruptcy of the people and proves, with the conclusion of the chapters, that Israel has not only not returned to YHWH but they have sunk even farther into the depths of sin as a result of choosing violence over the safety and well-being of the least of those in their midst.

\section{O PODER DE UMA MULHER IMPOTENTE: EXAMINANDO O IMPACTO DA VIOLÊNCIA EM UMA NAÇÃO BÍBLICA}

Resumo: Ela é sem nome e sem voz, violentamente estuprada e assassinada. A história da Concubina Levita ou Pilegesh, como disse nos últimos três capítulos do Livro dos Juízes, é frequentemente referida pelos estudiosos como um 
apêndice, indigno de ser considerado parte do panteão de juízes ilustres em Israel. No entanto, o relato da violação e assassinato de uma mulher indefesa e socialmente insignificante é mais do que uma história de violência contra as mulheres, é a história das consequências da violência e do poder que uma mulher pode ter sobre uma nação.

Palavras-chave: Livro dos Juízes. Levita. Concubina. Estupro. Assassinato. Juízes 19-21.

\section{Notes}

${ }^{1}$ The LXX and the NRSV add a sentence that declares her dead on the door step but the Hebrew text does not assign responsibility for her death to any one person or act.

${ }^{2}$ This is the only time the Ark of the Covenant is mentioned in Judges.

3 i.e. Israel sins, is in bondage, repents, and God sends a deliverer.

\section{References}

BACH, Alice. Rereading the Body Politic: Women, Violence and Judges 21. In: BRENNER, Athalya (Ed.). Judges: A Feminist Companion to the Bible. Sheffield: Sheffield Academic Press, 1999. p. 143-159.

BAILEY, Wilma Ann. "You shall not kill" or "You shall not murder"? The Assault on a Biblical Text. Collegeville: Liturgical Press, 2005.

BELLIS, Alice Ogden. Helpmates, Harlots, and Heroes: Women's Stories in the Hebrew Bible. Louisville: Westminster John Knox Press, 2007.

BERKELEY, James P. Knowing the Old Testament. Valley Forge: Judson Press, 1954.

BERLIN, Adele (Ed.). The Oxford Dictionary of the Jewish Religion. Oxford: OUP, 2011. (Volume 1).

BOTTERWECK, G. Johannes; RINGGREN, Helmer; FABRY, Heinz-Josef (Ed.). Theological Dictionary of the Old Testament. Grand Rapids: Wm. B. Eerdmans, 1977.

BROWN, Francis; DRIVER, R.; BRIGGS, Charles. The Brown-Driver-Briggs Hebrew and English Lexicon. Peabody: Hendrickson Publishers, 2005. 
The power of a powerless woman: examining the impact of violence...

COHN, Haim Herman; ELON, Menachem. Homicide. In: SKOLNIK, Fred; BERENBAUM, Michael (Ed.). Encyclopaedia Judaica. 2. ed. New York: Macmillan Publishers USA, 2007. p. 506-507. (Volume 9).

FREEDMAN, David Noel. The Nine Commandments: Uncovering the Hidden Pattern of Crime and Punishment in the Hebrew Bible. New York: Doubleday, 2000 .

(0) FRIEDMAN, Richard Elliott. Who Wrote the Bible? San Francisco: Harper San Francisco, 1997.

HARRELSON, Walter. Interpreting the Old Testament. New York: Holt, Rinehart and Winston, 1964.

KEEFE, Alice. Rapes of Women/Wars of Men. In: CAMP, Claudia; FONTAINE, Carole (Ed.). Women, War and Metaphor: Language and Society in the Study of the Hebrew Bible. Atlanta: Scholars' Press, 1993. p. 79-97. (Semeia, 61).

KLEIN, Lillian R. The Triumph of Irony in the Book of Judges. Sheffield: Sheffield Academic Press, 1988.

MARTIN, James D. The Book of Judges. Cambridge: Cambridge University Press, 1975.

MATTHEWS, Victor H. Judges and Ruth. Cambridge: Cambridge University Press, 2004. REIS, Pamela Tamarkin. The Levite's Concubine: New Light on a Dark Story. Scandinavian Journal of the Old Testament, v. 20, n. 1, p. 125-146, 2006.

SCHNEIDER, Tammi J. Judges: Studies in Hebrew Narrative \& Poetry. Berit Olam Collegeville: The Liturgical Press, 2000.

SWEENEY, Marvin. Davidic Polemics in the Book of Judges. Vetus Testamentum, Hudson, v. 47, n. 4, p. 517-528, 1997.

THE HOLY BIBLE. King James Version. Salt Lake City: The Church of Jesus Christ of Latter-day Saints, 1979.

TRIBLE, Phyllis. Texts of Terrors: Literary-Feminist Readings of Biblical Narratives. Philadelphia: Fortress Press, 1984.

YEE, Gale A (Ed.). Judges \& Method: New Approaches in Biblical Studies. Minneapolis: Fortress Press, 2007.

Recebido em: 01/12/2017

Aprovado em: 10/01/2018 